University of Nebraska - Lincoln

DigitalCommons@University of Nebraska - Lincoln

\title{
Natural product studies of U.S. endangered plants: Volatile components of Lindera melissifolia (Lauraceae) repel mosquitoes and ticks
}

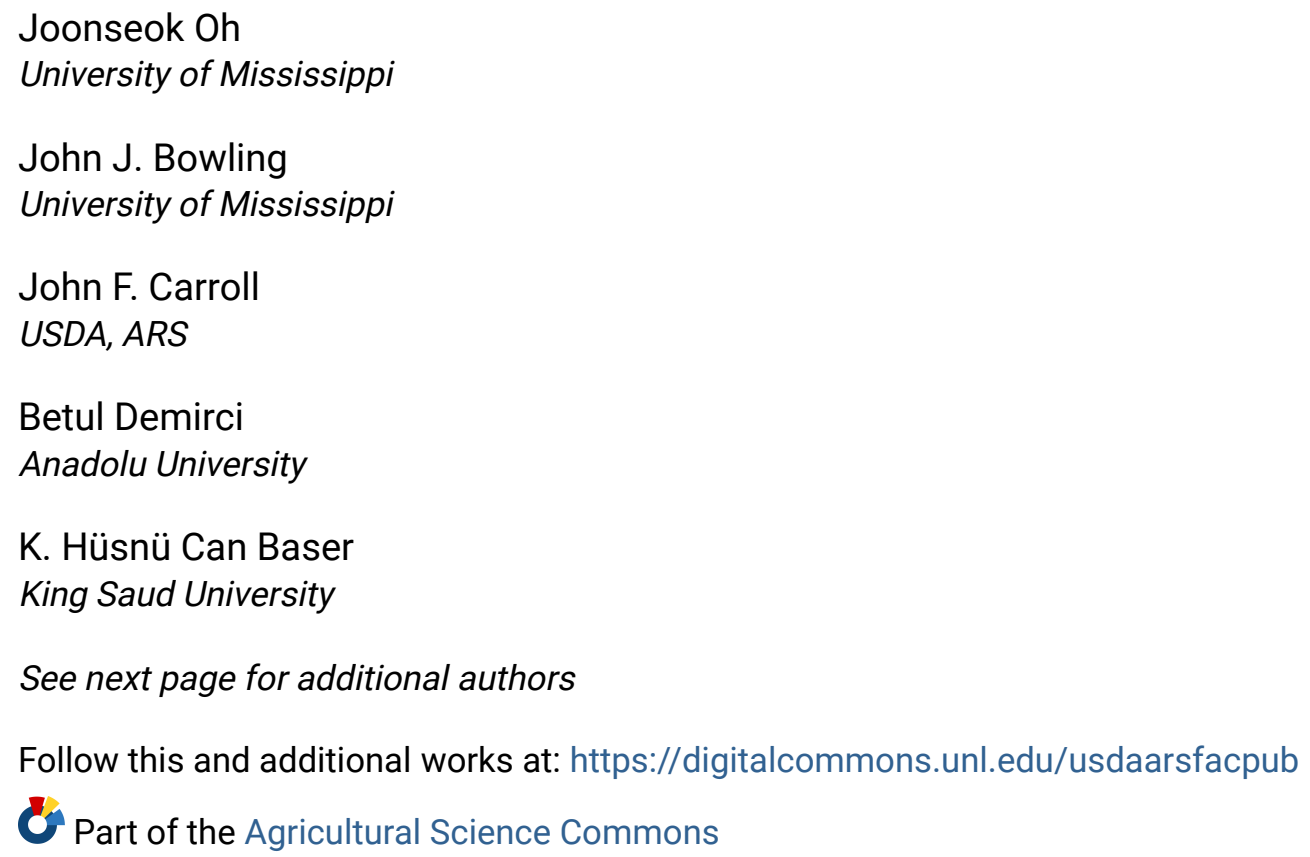

Oh, Joonseok; Bowling, John J.; Carroll, John F.; Demirci, Betul; Can Baser, K. Hüsnü; Leininger, Theodor D.; Bernier, Ulrich R.; and Hamann, Mark T., "Natural product studies of U.S. endangered plants: Volatile components of Lindera melissifolia (Lauraceae) repel mosquitoes and ticks" (2012). Publications from USDA-ARS / UNL Faculty. 971.

https://digitalcommons.unl.edu/usdaarsfacpub/971

This Article is brought to you for free and open access by the U.S. Department of Agriculture: Agricultural Research Service, Lincoln, Nebraska at DigitalCommons@University of Nebraska - Lincoln. It has been accepted for inclusion in Publications from USDA-ARS / UNL Faculty by an authorized administrator of DigitalCommons@University of Nebraska - Lincoln. 


\section{Authors}

Joonseok Oh, John J. Bowling, John F. Carroll, Betul Demirci, K. Hüsnü Can Baser, Theodor D. Leininger, Ulrich R. Bernier, and Mark T. Hamann 


\title{
Natural product studies of U.S. endangered plants: Volatile components of Lindera melissifolia (Lauraceae) repel mosquitoes and ticks
}

\author{
Joonseok Oh ${ }^{\text {a }}$, John J. Bowling ${ }^{\text {a }}$, John F. Carroll ${ }^{\mathrm{b}}$, Betul Demirci ${ }^{\mathrm{c}}$, K. Hüsnü Can Başer ${ }^{\mathrm{d}}$, \\ Theodor D. Leininger ${ }^{\mathrm{e}}$, Ulrich R. Bernier ${ }^{\mathrm{f}}$, Mark T. Hamann ${ }^{\mathrm{a}, *}$ \\ a Department of Pharmacognosy, School of Pharmacy, The University of Mississippi, University, MS 38677, United States \\ ${ }^{\mathrm{b}}$ USDA, ARS, IIBBL, Beltsville Agricultural Research Center, Beltsville, MD 20705, United States \\ ${ }^{\mathrm{c}}$ Anadolu University, Faculty of Pharmacy, Department of Pharmacognosy, 26470 Eskişehir, Turkey \\ d Botany and Microbiology Department, King Saud University, College of Science, 1145 Riyadh, Saudi Arabia \\ e USDA Forest Service, Center for Bottomland Hardwoods Research, 432 Stoneville Road, Stoneville, MS 38776, United States \\ ${ }^{\mathrm{f}}$ USDA-ARS-CMAVE, 1600 SW, 23rd Drive, Gainesville, FL 32608, United States
}

\section{A R T I C L E I N F O}

\section{Article history:}

Received 24 November 2011

Received in revised form 27 March 2012

Available online 14 June 2012

\section{Keywords:}

Lindera melissifolia

Lauraceae

Pondberry

Endangered species

Arthropod repellents

$\beta$-Caryophyllene

$\alpha$-Humulene

Germacrene D

$\beta$-Elemene

\begin{abstract}
A B S T R A C T
The number of endangered plant species in the U.S. is significant, yet studies aimed towards utilizing these plants are limited. Ticks and mosquitoes are vectors of significant pathogenic diseases of humans. Repellents are critical means of personal protection against biting arthropods and disease transmission. The essential oil and solvent extracts from Lindera melissifolia (Walt.) Blume (Lauraceae) (pondberry) drupes were gathered and analyzed by GC and GC-MS. The essential oil obtained from this endangered plant showed a significant dose dependent repellency of ticks and a moderate mosquito repellent effect while the subsequent hexanes extract was completely ineffective. Fractional freezing enriched the tick repellent components of the essential oil. Several known tick repellent components were recognized by the GC-MS comparison of the resulting fractions and $\beta$-caryophyllene, $\alpha$-humulene, germacrene D and $\beta$-elemene warrant evaluations for tick repellency. Identifying pondberry as a potential renewable source for a broad spectrum repellent supports efforts to conserve similar U.S. endangered or threatened plant species.
\end{abstract}

(c) 2012 Elsevier Ltd. All rights reserved.

\section{Introduction}

A recent report on the decline of global biodiversity suggests that the rate has not improved and that several factors have worsened the decline (Butchart et al., 2010). The pressure on biodiversity has been recognized for several years, yet progress toward limiting exacerbating factors worldwide appears sluggish. Globally at least $13 \%$ of known flora are endangered or threatened (Pitman and Jørgensen, 2002) and recently the USDA (USDA, 2011) claimed that there are now over 780 endangered or threatened species of plants in the U.S. and its territories. Although environmental factors such as habitat destruction, fragmentation, or climate change (Kotiaho, 2005) are the most widespread causes of species endangerment in the U.S. (Kotiaho, 2005), biological threats such as competition with non-native species and invasion of fungi (Lee et al., 1995), viruses (Jensen, 2007) or exotic arthropods (Center for Plant Conservation, 2011) are also significant factors driving plant species to extinction.

\footnotetext{
* Corresponding author. Tel.: +1 662915 5730; fax: +1 6629156975.

E-mail address: mthamann@olemiss.edu (M.T. Hamann).
}

Members of the Lauraceae are generally known for their high content of essential oils used in the perfume and spice industry and comprise about 55 genera and over 2000 species found (Joshi et al., 2010). Several studies on essential oils of the family describe associated chemistry as well as a variety of bioactivities (Baratta et al., 1998; Moriarity et al., 2007; Samarasekera, 2005; Schmidt et al., 2006; Semwal et al., 1999). Lindera melissifolia, commonly known as pondberry, is a member of the Lauraceae family but has not been investigated for its chemical constituents. It is an aromatic, rhizomatous, dioecious shrub that grows in seasonally flooded wetlands and on the edges of sinks and ponds in the Southeastern United States (Radford et al., 1968; U. S. Fish and Wildlife Service, 1993). The U.S. Fish and Wildlife Service listed pondberry as an endangered species in 1986 (U. S. Fish and Wildlife Service, 1986) because of habitat loss (U. S. Fish and Wildlife Service, 1993).

During the past approximately 30 years, Lyme disease has become a major human health problem in the U.S. with tens of thousands of cases reported annually (CDC, 2007; Parola and Raoult, 2001). In New England, the Mid-Atlantic and the Great Lake areas, the causative spirochete Borrelia burgdorferi Johnson, Schmid, Hyde, Steigerwalt and Brenner is transmitted by the bite of the 
blacklegged tick, Ixodes scapularis Say, whereas on the West Coast the Pacific blacklegged tick, Ixodes pacificus Cooley and Kohls, is the vector of B. burgdorferi (Sonenshine, 1993; Spielman et al., 1985). Populations of another tick of medical and veterinary importance, the lone star tick, Amblyomma americanum (L.) (Goddard and Varela-Stokes, 2009) has spread from South Central and Southeastern states northward and somewhat westward into the Mid-Atlantic U.S. states (Ginsberg et al., 1991).

Mosquitoes are the other taxon of hematophagous arthropods of major importance in transmitting disease agents and are the vectors of malaria, Japanese encephalitis, yellow fever, filariasis, as well as dengue fever (Rozendaal, 1997). The distribution and abundance of these diseases are influenced by the presence of humans and the level of poverty (de Mendonça et al., 2005). In the U.S., mosquito-transmitted West Nile virus infected 8000 people from 1999 to 2005, resulting in 780 recorded deaths (DeBiasi and Tyler, 2006).

With proper application, insect repellents reduce disease transmission caused by arthropod vectors (Rozendaal, 1997). DEET ( $N$, $\mathrm{N}$-diethyl-3-methylbenzamide) is a broad-spectrum synthetic repellent that has been effective against several species of mosquitoes, chiggers, ticks and biting flies (Barnard and Xue, 2004; Carroll et al., 2005; Evans et al., 1990; Schreck et al., 1995; Yap et al., 2000). However, repeated use of synthetic repellents disrupts natural biological systems and promotes resistance (Brown, 1983; Rozendaal, 1997) and DEET has been reported to exert toxic reactions in humans under some circumstances and age groups (Briassoulis et al., 2001; Clem et al., 1993).

Plants are considered to be a source of safe repellents since they may have less harmful side effects from regular use (Bissinger and Roe, 2010). A number of essential oils from plants exhibit insect repellent properties (Bissinger and Roe, 2010). Natural repellents are commonly regarded to be effective for short durations but some botanically based repellents such as $p$-menthane-3,8-diol (PMD) from the lemon-scented gum tree, Corymbia citriodora have recently shown sustained potency for protection against mosquitoes (Jaenson et al., 2006; Peterson and Coats, 2001). Consequently more interest has been focused on plant extracts or essential oils as potential alternative repellent agents (Yang et al., 2004).

As part of a conscious effort to conserve plant resources that still exist in the U.S. but are threatened with extinction, the chemical constituents and potential biomedical uses of pondberry were investigated. The crude essential oil of fresh pondberry drupes was collected and the oil and a subsequent hexanes extract were evaluated for insecticidal and repellent activity against mosquitoes and ticks.

\section{Results and discussion}

\subsection{Crude essential oil analysis}

GC and GC-MS analysis was used to extensively investigate the components of the essential oil and hexanes extract from L. melissifolia drupes (Table 1). The major components of the essential oil extract were sabinene (66.2\%), (E)- $\beta$-ocimene (12.9\%), $\alpha$-phellandrene $(4.1 \%), \beta$-caryophyllene $(2.6 \%)$, limonene $(2.3 \%)$, myrcene (2.1\%) and $p$-cymene $(0.5 \%)$ and these were confirmed by $1 \mathrm{D}$ and 2D NMR spectroscopic analysis (Fig. S3 in Supplementary data). In the ${ }^{1} \mathrm{H}$ NMR spectrum (Fig. 1), component (ii) shares the significant signals of exo-olefinic (4.65-4.84 ppm) and cyclopropyl functional groups (0.66-0.68 $\mathrm{ppm})$ indicating the presence of sabinene which was proven to be the most abundant component in the essential oil by GC and GC-MS analyses. Further NMR spectroscopic analyses, including the broadband $1 \mathrm{D}^{13} \mathrm{C}$, HSQC (Fig. S3 in Supplementary data) and $\mathrm{HMBC}$ were performed to dereplicate the structure of sabinene. The presence of a relatively strong signal for component (i) at $6.39 \mathrm{ppm}$ split with typical cis and trans ${ }^{3}$ $J$-couplings (dd, $J=17.6,10.7 \mathrm{~Hz}$ ) implied the presence of a vinyl group. Comparison of the chemical shifts of the ${ }^{1} \mathrm{H}$ and ${ }^{13} \mathrm{C}$ NMR resonances and their relative intensities with literature data indicated that component (i) was (E)- $\beta$-ocimene. An aromatic signal for component $(\mathrm{v})$ at $7.13 \mathrm{ppm}(\mathrm{d}, J=2.3 \mathrm{~Hz})$ suggested the presence of a phenyl ring. Further NMR analysis characterized the component as $p$-cymene. Normal phase preparative HPLC provided a purified component, trans-sabinene hydrate (Fig. S4 in Supplementary data) (Kubeczka and Formácek, 2002).

\subsection{Mosquito repellency}

The mosquito repellent activity was relatively marginal compared to DEET. Only the highest concentration of the hexanes extract tested was repellent (Table S1 in Supplementary data). One or more constituents of the oil, likely at low abundance, are

Table 1

GC and GC-MS analyses of L. melissifolia drupes essential oil (sample A) and hexanes extract (sample B).

\begin{tabular}{|c|c|c|c|c|c|c|c|c|c|c|c|}
\hline $\mathrm{RRI}^{\mathrm{a}}$ & Components & $\mathrm{A} \%{ }^{\mathrm{b}}$ & $\mathrm{B} \% \mathrm{~b}$ & $\mathrm{RRI}^{\mathrm{a}}$ & Components & $\mathrm{A} \%{ }^{\mathrm{b}}$ & $\mathrm{B} \% \mathrm{~b}$ & $\mathrm{RRI}^{\mathrm{a}}$ & Components & $\mathrm{A} \% \mathrm{~b}$ & $\mathrm{~B} \%$ \\
\hline 1000 & Decane & & 0.2 & 1290 & Terpinolene & 0.5 & 0.3 & 1740 & $\alpha$-Muurolene & & $\operatorname{tr}$ \\
\hline 1032 & $\alpha$-Pinene & 1.0 & 0.1 & 1474 & Trans-sabinene hydrate & 0.2 & 0.5 & 1765 & Geranyl acetate & 0.2 & 2.2 \\
\hline 1035 & $\alpha$-Thujene & 0.5 & 0.1 & 1487 & Citronellal & 0.6 & 1.1 & 1772 & Citronellol & 0.5 & 4.3 \\
\hline 1058 & 3-Hexanone & & 0.4 & 1497 & $\alpha$-Copaene & & 0.4 & 1773 & $\delta$-Cadinene & & 0.7 \\
\hline 1072 & $\alpha$-Fenchene & 0.1 & & 1544 & $\alpha$-Gurjunene & & 0.3 & 1807 & $\alpha$-Cadinene & & 0.3 \\
\hline 1076 & Camphene & 0.1 & & 1549 & $\beta$-Cubebene & & 0.2 & 1808 & Nerol & $\operatorname{tr}$ & $\operatorname{tr}$ \\
\hline 1118 & $\beta$-Pinene & 1.2 & 0.3 & 1542 & cis-Sabinene hydrate acetate & $\operatorname{tr}^{c}$ & 0.1 & 1857 & Geraniol & $\operatorname{tr}$ & 0.3 \\
\hline 1132 & Sabinene & 66.2 & 17.7 & 1553 & Linalool & $\operatorname{tr}$ & 0.2 & 2008 & Caryophyllene oxide & & 0.4 \\
\hline 1159 & $\delta$-3-Carene & 0.2 & & 1572 & Pregeijerene B & 0.2 & 0.4 & 2069 & Germacrene D-4 $\beta$-ol & & 3.9 \\
\hline 1174 & Myrcene & 2.1 & 0.4 & 1589 & $\beta$-Ylangene & & 1.1 & 2096 & Elemol & & 6.6 \\
\hline 1176 & $\alpha$-Phellandrene & 4.1 & 1.1 & 1591 & Bornyl acetate & 0.2 & 0.4 & 2187 & T-Cadinol & & 0.2 \\
\hline 1188 & $\alpha$-Terpinene & 0.2 & $\operatorname{tr}$ & 1600 & $\beta$-Elemene & & 1.5 & 2226 & Methyl palmitate & & 0.3 \\
\hline 1203 & Limonene & 2.3 & 0.3 & 1612 & $\beta$-Caryophyllene & 2.6 & 15.5 & 2255 & $\alpha$-Cadinol & & 0.2 \\
\hline 1213 & 1,8-Cineole & 1.1 & $\operatorname{tr}$ & 1659 & $\gamma$-Gurjunene & & 0.6 & 2257 & $\beta$-Eudesmol & & 0.2 \\
\hline 1218 & $\beta$-Phellandrene & 0.5 & $\operatorname{tr}$ & 1668 & Citronellyl acetate & 0.3 & 1.7 & 2260 & Citronellic acid & & 0.4 \\
\hline 1246 & 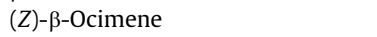 & 0.2 & $\operatorname{tr}$ & 1687 & $\alpha$-Humulene & 0.1 & 1.5 & 2369 & $(2 E, 6 E)$-Farnesol & & $\operatorname{tr}$ \\
\hline 1255 & $\gamma$-Terpinene & 0.3 & $\operatorname{tr}$ & 1704 & $\gamma$-Muurolene & & 0.2 & 2431 & Methyl stearate & & 0.7 \\
\hline 1266 & (E)- $\beta$-Ocimene & 12.9 & 3.0 & 1706 & $\alpha$-Terpineol & 0.1 & 0.4 & 2456 & Methyl oleate & & 2.3 \\
\hline 1280 & p-Cymene & 0.5 & 0.2 & 1726 & Germacrene D & 0.8 & 13.4 & 2492 & Ethyl oleate & & 0.2 \\
\hline \multirow[t]{2}{*}{1286} & 2-Methyl butyl 2-methyl butyrate & 0.2 & $\operatorname{tr}$ & 1733 & Neryl acetate & $\operatorname{tr}$ & 0.4 & 2509 & Methyl linoleate & & 1.5 \\
\hline & & & & & & & & 2931 & Hexadecanoic acid & & 2.7 \\
\hline
\end{tabular}

\footnotetext{
a Relative retention indices calculated against $n$-alkanes.

b Calculated from GC-FID data.

c Trace $(<0.1 \%)$.
} 
producing some weak repellency. As part of another study sabinene, the primary constituent of L. melissifolia oil, has been tested and found not to be repellent up to the $0.187 \mathrm{mg} / \mathrm{cm}^{2}$ level.
However, an examination of Hedychium spp., showed that $\alpha$-terpineol (minimum effective dose (MED) of $0.039 \pm 0.008 \mathrm{mg} / \mathrm{cm}^{2}$ ) and linalool (MED of $0.125 \pm 0.031 \mathrm{mg} / \mathrm{cm}^{2}$ ) are candidates for

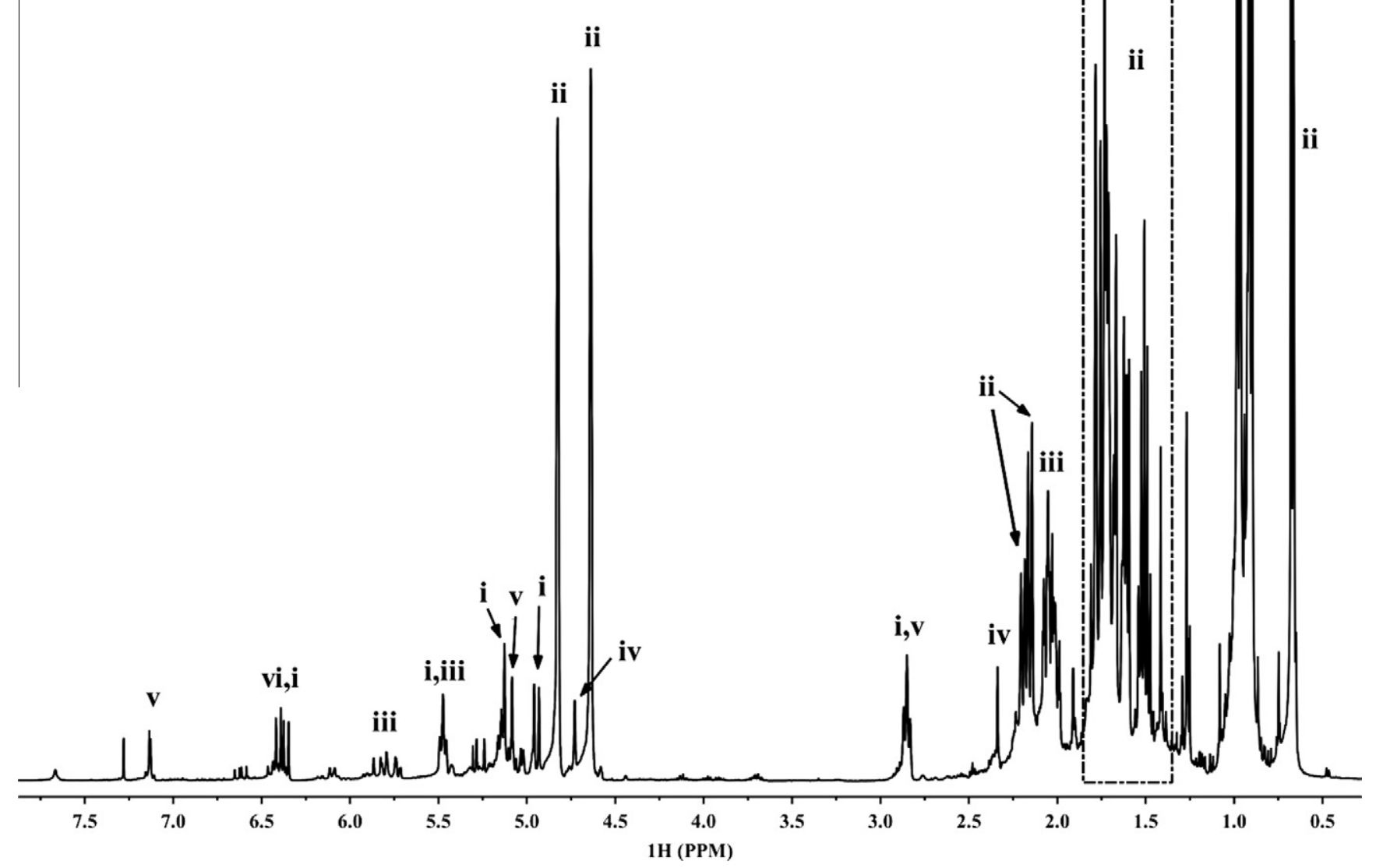

Fig. 1. ${ }^{1} \mathrm{H}$ NMR spectrum of pondberry essential oil and identified major components of the oil ( $\mathrm{CDCl}_{3}, 400 \mathrm{MHz}$ ). (i) (E)- $\beta$-ocimene, (ii) sabinene, (iii) $\alpha$-phellandrene, (iv) limonene, (v) p-cymene, (vi) myrcene.
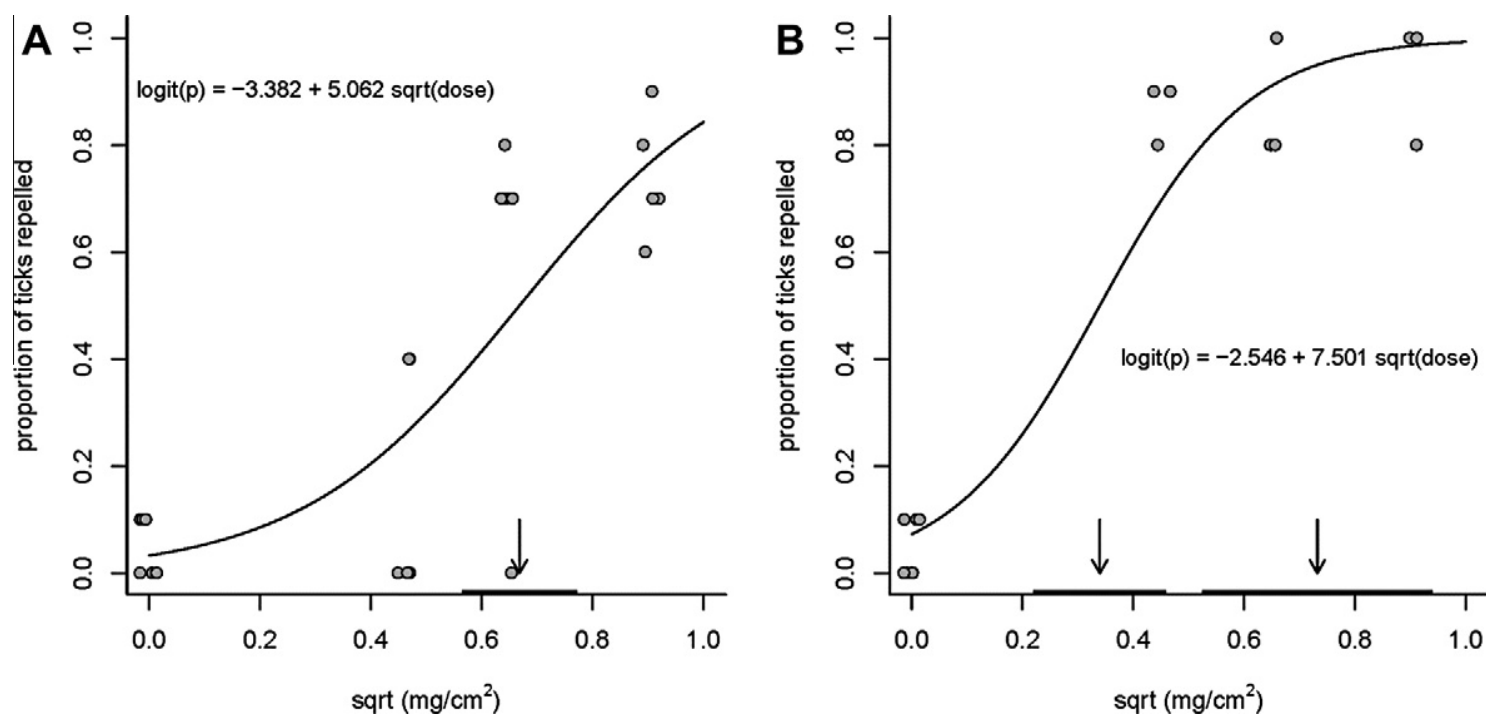

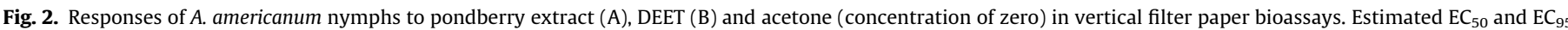
(B only) indicated by arrows and $95 \%$ confidence intervals by horizontal bars flush with the $x$-axis. 
Table 2

Concentrations of $L$. melissifolia essential oil and DEET estimated to repel $50 \%$ and $95 \%$ of $A$. americanum nymphs.

\begin{tabular}{|c|c|c|c|c|}
\hline Sample & Concentration $^{\mathrm{a}}$ (Power transformation) $( \pm \mathrm{SE})$ & Intercept $( \pm S E)$ & Slope $( \pm S E)$ & Dispersion parameter \\
\hline Essential oil & $\begin{array}{l}\mathrm{EC}_{50} 0.668 \text { (sqrt) }( \pm 0.050) \\
\mathrm{EC}_{95} 1.250 \text { (sqrt) }( \pm 1.250)\end{array}$ & $-3.3820( \pm 0.695)$ & $5.062( \pm 1.051)$ & 2.050 \\
\hline DEET & $\begin{array}{l}\mathrm{EC}_{50} 0.339 \text { (sqrt) }( \pm 0.058) \\
\mathrm{EC}_{95} 0.731 \text { (sqrt) }( \pm 1.022)\end{array}$ & $-2.546( \pm 0.719)$ & $7.501( \pm 1.640)$ & 2.663 \\
\hline
\end{tabular}

a Concentrations as mg extract or DEET $/ \mathrm{cm}^{2}$ filter paper.

repellents (Sakhanokho et al. unpublished results). Linalool is a well-documented attraction-inhibitor and topical repellent of mosquitoes (Kline et al., 2003; Müller et al., 2008).

\subsection{Lone star tick and blacklegged tick repellency of the crude pondberry essential oil}

In the vertical filter paper bioassay, the pondberry extract at $0.827 \mathrm{mg}$ extract $/ \mathrm{cm}^{2}$ filter paper repelled $74 \%$ of the A. americanum nymphs ( $7.40 \pm 0.51$ of 10 ticks per replicate) and was significantly more repellent than the acetone $\operatorname{control}(P=0.001)$. DEET repellence was $93 \%$ ( $9.33 \pm 0.67$ of 10 ticks per replicate). The fit of the data for determining $\mathrm{EC}_{50}$ and $\mathrm{EC}_{95}$ values, the slopes and intercepts of the regression equations, and dispersion parameters for the pondberry extract and DEET are shown in Fig. 2 and Table 2. There was no $\mathrm{EC}_{95}$ determined for repellency of the pondberry extract because the necessary proportion of ticks was not repelled. The slope of the regression equation for DEET was significantly higher $(P=0.001)$ than that of the pondberry extract. At $0.413 \mathrm{mg} / \mathrm{cm}^{2}$ filter paper, pondberry extract repelled significantly more I. scapularis adults per replicate $(P<0.0001)$ with an average of $9.75 \pm 0.25(97.5 \%)$ ticks repelled compared to the acetone controls with $1.67 \pm 0.33(16.1 \%)$ adults repelled. This contrasts with $A$. americanum which required an estimated $0.668 \pm 0.05 \mathrm{mg}$ extract $/ \mathrm{cm}^{2}$ filter paper to repel half the ticks (Table 2). Sabinene was ineffectual $(P=0.3168)$ against $A$. americanum nymphs at $2000 \mathrm{nmol} / \mathrm{cm}^{2}$ filter paper repelling an average of just $1.33 \pm 0.88$ (13.3\%) ticks per replicate. However, the same concentration of trans-sabinene hydrate repelled an average of $5.0 \pm 1.0(50 \%)$ A. americanum nymphs per replicate $(P=0.0398)$. Pondberry extract is clearly repellent to A. americanum and $I$. scapularis and apparently more so to I. scapularis. Other repellents (e.g. DEET, SS220) tested in the vertical filter paper bioassay have also tended to require higher concentrations to repel $A$. americanum nymphs than to repel $I$. scapularis nymphs (Carroll et al., 2004). Trans-sabinene hydrate, a minor constituent $(0.2 \%$ of the pondberry essential oil), showed some moderate repellent activity against $A$. americanum and may act in conjunction with other minor components.

\subsection{Analysis and tick repellency of essential oil fractions}

After the crude pondberry oil was shown to be an effective repellent against ticks, a solvent-efficient method was devised to enrich the active components. Fractional freezing has been traditionally utilized for purifying solvents using their different freezing points (Matthews and Coggeshall, 1959; Sköld et al., 1976) and was employed to separate groups of volatile components from the pondberry drupes accordingly (Fig. 3 and Table S3 in Supplementary data). The stacked GC-MS chromatograms are shown in Fig. 3. The most abundant monoterpene in the crude oil was sabinene and likewise it dominated all but the $-20^{\circ} \mathrm{C}$ fraction. Fractions $-20^{\circ} \mathrm{C}$ and $-42{ }^{\circ} \mathrm{C}$ repelled the $A$. americanum ticks to a similar extent as the crude oil (Fig. 4), indicating that fractional freezing facilitated the accumulation of tick repellent components from the essential oil. Comparative analysis of each fraction (Fig. 5 and Table S3 in Supplementary data) identified previously reported tick repellents [gera- niol $(S)$, citronellol $(A F)$, geranyl acetate $(A D)$, citronellal $(Q)$, terpinen-4-ol (U) and citronellyl acetate (AB)] (Weldon et al., 2011 ) and suggests that additional components [myrcene (F), bornyl acetate $(T), \beta$-caryophyllene (W), $\alpha$-humulene $(X)$, germacrene $\mathrm{D}(\mathrm{Y})$ and $\beta$-elemene $(\mathrm{AE})]$ may also have repellent activity.

\section{Conclusions}

GC and GC-MS analyses of the essential oil from L. melissifolia drupes identified various monoterpenes and sesquiterpenes (Table 1 ). The majority of the pondberry essential oil and its hexanes extract was sabinene. The NMR fingerprinting process supported by GC and GC-MS verified that (E)- $\beta$-ocimene, sabinene, $\alpha$-phellandrene, limonene, $p$-cymene and myrcene were characteristic markers of the essential oil from pondberry. The essential oil repelled both the lone star and blacklegged ticks and showed modest mosquito repellent activity which indicates that the pondberry essential oil could be a resource for a broad spectrum arthropod repellent. Fractional freezing proved to be an effective and solvent-efficient method to accumulate the tick repellent components in the pondberry essential oil. Although extraction with hexanes may provide a similar product (Table 1) it is not clear from our tests if the product would be active as a tick repellent. Based on our analysis of the fractions generated by fractional freezing (Fig. 5), $\beta$-caryophyllene $(W), \alpha$-humulene $(X)$, germacrene $D(Y)$ and $\beta$-elemene $(\mathrm{AE})$ warrant further investigation as tick repellents. Although the reported compounds may be readily obtained from other plant sources or synthetic routes, agricultural techniques involving strain selection based on the plant's metabolome may also satisfy supply requirements. In addition the endangered plant metabolome would provide a valuable tool for strain selection for disease and insect resistance. Thus utilization of products obtained from an endangered or threatened plant species can potentially support their conservation and commercial development.

\section{Experimental}

\subsection{General experimental procedures}

NMR spectra were obtained using a Bruker Avance $400 \mathrm{MHz}$ spectrometer referenced by a residual $\mathrm{CH}_{2} \mathrm{Cl}_{2}$ and $\mathrm{CHCl}_{3}$ signals. Precoated silica gel 60 F254 plates from Merck were used for TLC. Pentane and $\mathrm{CH}_{2} \mathrm{CL}_{2}$ (4:1) was used to develop the TLC. A vanillinsulfuric acid stain and iodine were used for visualizing TLC. HPLC was carried out with a Phenomenex Silica column $(10 \times 250 \mathrm{~mm}$, $5 \mu \mathrm{m}$ ) for semipreparative injections with a Waters dual pump model 510 (flow rate $8 \mathrm{~mL} / \mathrm{min}$ ) and a UV absorbance detector model 486 and with fraction collection at 1 min increments using a Foxy 200 fraction collector. Fractions were detected by TLC. $N, N$-Diethyl3-methylbenzamide (DEET) and trans-sabinene hydrate used for the tick and mosquito assays were purchased from Sigma-Aldrich, Inc., St. Louis, MO. Sabinene was isolated from the pondberry essential oil using standard chromatography techniques. Trans-sabinene hydrate was purified from the pondberry crude oil by an HPLC method employing the semipreparative silica column eluting with pentane and dichloromethane. 


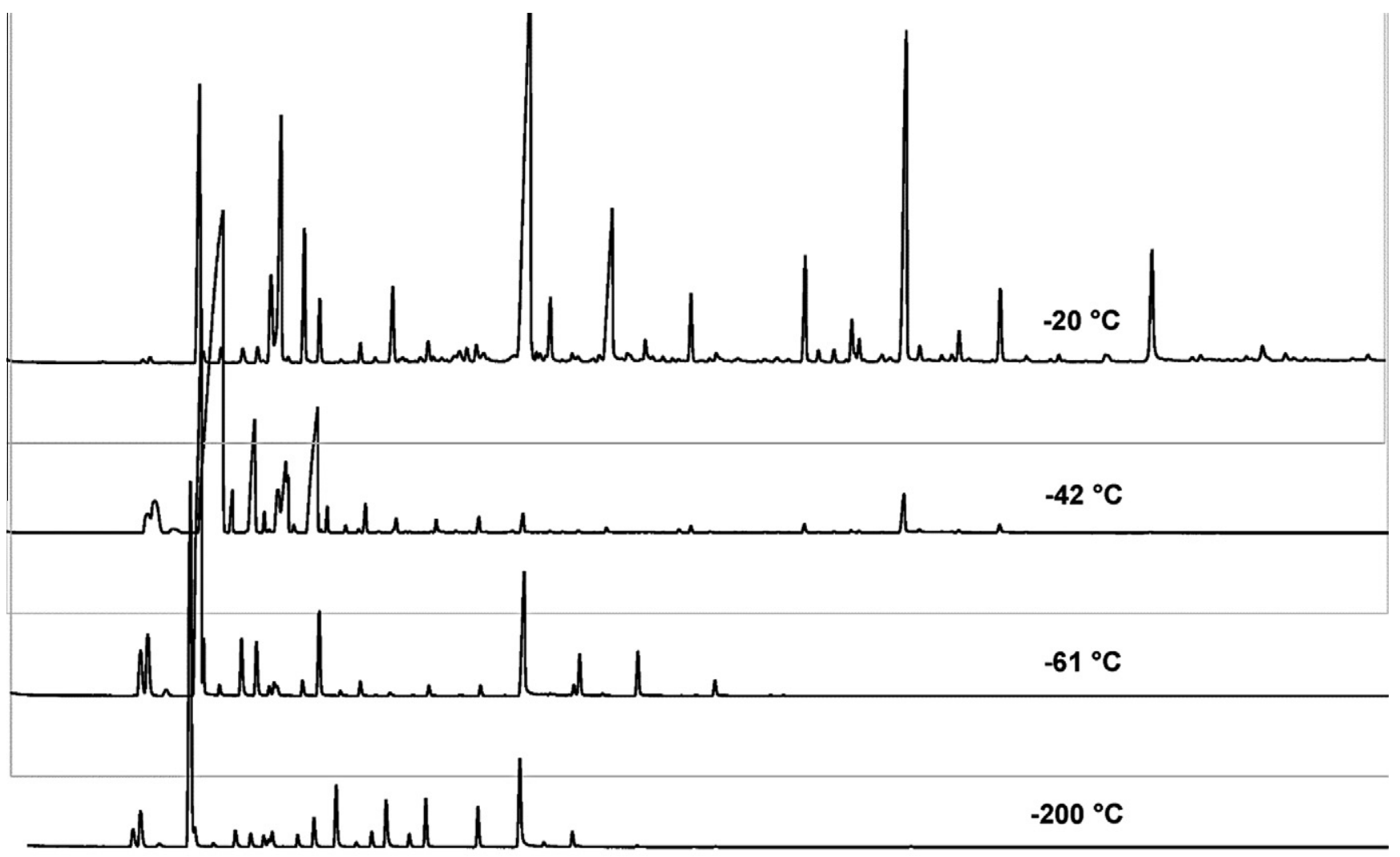

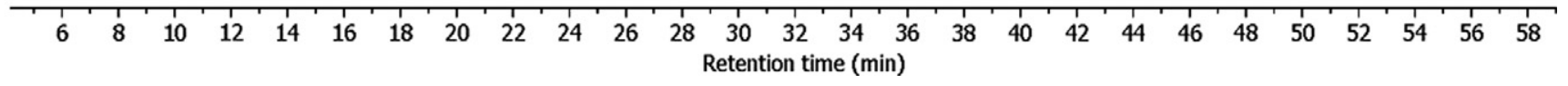

Fig. 3. GC and GC-MS chromatograms of fractions generated by fractional freezing (from top $\left(-20^{\circ} \mathrm{C}\right)$ to bottom $\left(-200{ }^{\circ} \mathrm{C}\right)$ ).

\subsection{Plant material}

The drupes of L. melissifolia (5 $\mathrm{kg}$ ) were collected in September 2009 at a research facility (Flooding Research Facility, FRF) (Lockhart et al., 2006) on U.S. Fish and Wildlife Service land in Sharkey County, Mississippi and jointly maintained by the USFWS and the U.S. Forest Service and identified by Danny Skojac and Tracy Hawkins (USDA Forest Service). The drupe sample was combined from plants of nine female clones previously collected from the Delta National Forest, Sharkey Co., MS and USFWS property in Bolivar Co., MS that were reproduced from tissue culture (Hawkins et al., 2007) and planted into the FRF for a large-scale physiology experiment. A voucher specimen (\# 01157) has been deposited at the Herbarium of the U.S. Forest Service Southern Hardwoods Laboratory, Washington Co., MS (Fig. S2 in Supplementary data).

\subsection{Essential oil extraction}

Pondberry drupes ( $5 \mathrm{~kg}$ ) were coarsely ground in a blender and placed in the chamber of a Speed Vac ${ }^{\infty}$ (SC210A) evaporator. The essential oil was collected in the glass chamber of a Refrigerated Vapor Trap (ca. $\left.100{ }^{\circ} \mathrm{C}\right)($ RVT 4104$)$ under high vacuum. The contents of the trap were defrosted and extracted with $\mathrm{CH}_{2} \mathrm{Cl}_{2}(4 \times 10 \mathrm{~mL})$. Removal of the residual solvent was completed under $\mathrm{N}_{2}$. The yield of the crude oil was approximately $30 \mathrm{~g}(0.6 \%$ wet wt) and the oil was stored at $-20^{\circ} \mathrm{C}$. The remaining material was extracted three times by ultrasound in hexanes, which yielded hexanes extract (300 g).

\subsection{GC, GC-MS and NMR analysis of crude essential oil}

GC-MS analysis was carried out with an Agilent 5975 GC-MSD system. An Innowax FSC column $(60 \mathrm{~m} \times 0.25 \mathrm{~mm}, 0.25 \mu \mathrm{m}$ film thickness) was used with He as carrier gas $(0.8 \mathrm{~mL} / \mathrm{min})$. The GC oven temperature was kept at $60^{\circ} \mathrm{C}$ for $10 \mathrm{~min}$ and increased to $220^{\circ} \mathrm{C}$ at a rate of $4{ }^{\circ} \mathrm{C} / \mathrm{min}$, kept constant at $220^{\circ} \mathrm{C}$ for $10 \mathrm{~min}$ and then increased to $240{ }^{\circ} \mathrm{C}$ at a rate of $1{ }^{\circ} \mathrm{C} / \mathrm{min}$. Split ratio was adjusted at $40: 1$. The injector temperature was set at $250^{\circ} \mathrm{C}$. Mass spectra were recorded at $70 \mathrm{eV}$ with a mass range was from $\mathrm{m} / \mathrm{z}$ 35-450. The GC was carried out using an Agilent 6890 N GC system. The FID detector temperature was $300^{\circ} \mathrm{C}$. To obtain the same elution order with GC-MS, simultaneous auto-injection was done on a duplicate of the same column applying the same operational conditions. Relative percentage amounts of the separated components were calculated from FID chromatograms. Identification of the essential oil components was carried out by comparison of their relative retention times with those of authentic samples or by comparison of their relative retention index (RRI) to a series of $n$-alkanes. Component identification was completed by computer matching against commercial databases (Wiley GC/MS Library, Adams Library, MassFinder 3 Library) (Koenig et al., 2004; McLafferty and Stauffer, 1989), and the in-house "Başer Library of Essential Oil Constituents" (built up by genuine compounds and components of known oils as well as MS literature data (ESO 2000, 1999; Joulain and Koenig, 1998). Major components of pondberry essential oil, i.e. (E)- $\beta$-ocimene, sabinene, $\alpha$-phellandrene, limonene, $p$-cymene, myrcene and $\beta$-caryophyllene 


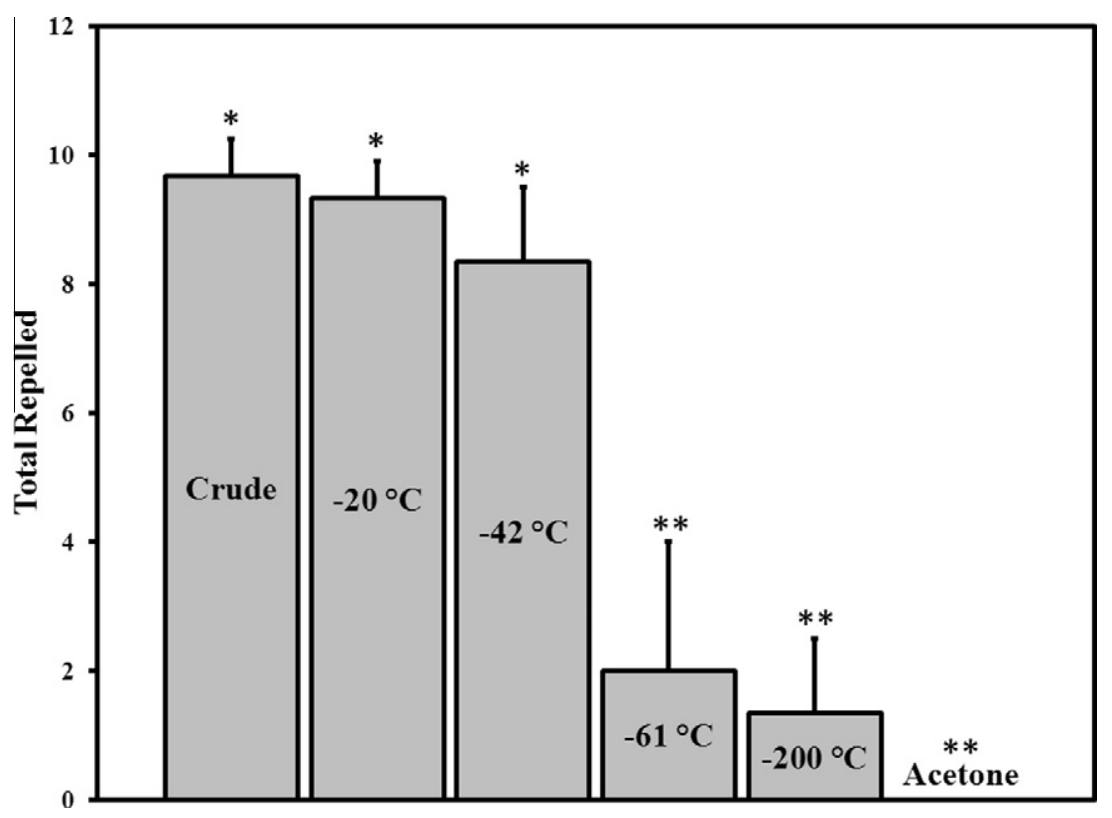

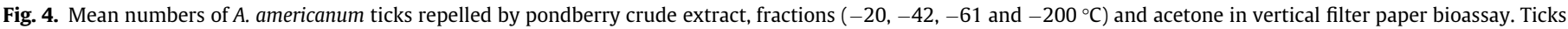

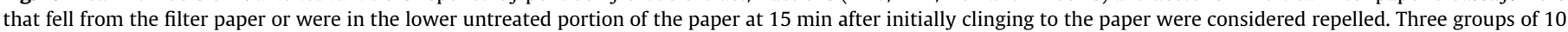
ticks each were tested per extract, fraction and acetone control. Columns with the same number of asterisks do not differ significantly $(P>0.05)$ according to ANOVA.

were also characterized by comparison of ${ }^{1} \mathrm{H}$ and ${ }^{13} \mathrm{C}$ NMR chemical shift data with literature data (Guerrini et al., 2006; Kubeczka and Formácek, 2002).

\subsection{Mosquito repellent assay}

Aedes aegypti pupae from the Gainesville 1952 Orlando colony strain at CMAVE were maintained in the laboratory at $28 \pm 1^{\circ} \mathrm{C}$ and $30-60 \%$ relative humidity $(\mathrm{RH})$ until adults emerged. Adults 5-9 days old were used in tests ( $12 \mathrm{~h}$ simulated light, $10 \%$ sucrose). Host-seeking mosquitoes were drawn from stock cages using a hand-draw box (Posey and Schreck, 1981). Approximately 500 $( \pm 10 \%)$ female mosquitoes were collected and placed into a $59,000 \mathrm{~cm}^{3}$ test cage (dimensions $45 \times 37.5 \times 35 \mathrm{~cm}$ ) and held for $25( \pm 2.5)$ min before testing repellency (Barnard et al., 2007). Test samples were weighed and placed in two dram vials to which $2 \mathrm{~mL}$ acetone was added. The sample wt of DEET and the essential oil was adjusted by removal of half the solution to produce an initial concentration of $1.5 \mathrm{mg} / \mathrm{cm}^{2}$ on a $50 \mathrm{~cm}^{2}$ muslin cloth in the vials. The hexanes extract provided only sufficient sample for an initial concentration of $0.75 \mathrm{mg} / \mathrm{cm}^{2}$ on the cloth. Twofold serial dilutions were made analogously and vials were sealed and stored $\left(-4{ }^{\circ} \mathrm{C}\right)$ until testing. Prior to testing, the pieces of cloth were removed from the vial and stapled and taped $(2.5-5.0 \mathrm{~cm}$ long) onto two sections of card stock $(5 \times 2.5 \mathrm{~cm})$ and placed on a drying rack for 3-5 min.

The order in which treated cloths were tested was randomized among volunteers and randomized to minimize any variation due to day-to-day effects. During a test, all volunteers wore a patch and tested each patch for $1 \mathrm{~min}$ intervals. Patches were rotated between the volunteers, thus, no patch was evaluated beyond 5 min after the 3 min drying period to avoid any bias that may result from evaporative loss of the treatment from the cloth during the duration of the test. Three male volunteers (two tested twice) and a female volunteer participated in the studies of the minimum effective dosage (MED) of the oil, extract and DEET. Details of the remaining test procedures including the evaluation of the mosquito bite results can be found in previous studies excluding the minor modifications described herein (Katritzky et al., 2010). The volunteers in this study provided written informed consent and the protocol was approved by the University of Florida Human Use Institutional Review Board-01 (Study \# 636-2005).

\subsection{Tick repellent assay}

The A. americanum nymphs were obtained from a colony at Oklahoma State University, Stillwater, OK and held at $23-24^{\circ} \mathrm{C}$, $\approx 97 \%$ RH and a photoperiod of 16:8 h (L:D). Adult I. scapularis female ticks were captured by flagging at the USGS Patuxent Wildlife Research Center, Laurel, MD. Because peak host-seeking by adult $I$. scapularis is during the cooler months in Maryland, the ticks were maintained in the laboratory at $15-17^{\circ} \mathrm{C}, \approx 97 \%$ R.H. and a photoperiod of $11: 13 \mathrm{~h}$ (L:D). The A. americanum nymphs were tested 1-3 months after molting and the I. scapularis were tested 1.52 months after capture. Test solutions of pondberry extracts were prepared in acetone, sabinene and trans-sabinene hydrate were prepared in ethyl acetate. The repellent activity of the test solutions was evaluated by using an in vitro bioassay, described in detail by Carroll et al. (2004) based on the tendency of host-seeking ticks to climb. A $4 \times 7$-cm rectangle of Whatman No. 4 filter paper was marked with two parallel pencil lines that created two $1 \times$ $4-\mathrm{cm}$ zones at either of the far ends of the paper with a central $4 \times 5$-cm zone between them. Test solutions $(165 \mu \mathrm{L})$ were evenly applied with a pipet to the $20-\mathrm{cm}^{2}$ central zone of the filter paper strip. The strip was allowed to dry for 10-15 min and suspended from a bulldog clip hung from a slender dowel held by an Aptex No. 10 double clip workholder (Aptex Corp., Bethel, CT). The vertical strip hung over moated Petri dishes (a $9 \mathrm{~cm}$ diameter dish glued in a $15 \mathrm{~cm}$ diameter dish with water filling the space between their walls). The moated Petri dish beneath the strip confined ticks that dropped from the paper strip. A storage vial containing ticks was opened in the center of another set of moated Petri dishes (5.5 and $9 \mathrm{~cm}$ diameters). When $A$. americanum nymphs had crawled onto the rim of the vial and the Petri dish, the strip was removed from the peg and held so that a total of 10 ticks crawled onto the lower untreated zone. Adult I. scapularis were allowed to adjust to the ambient temperature $\left(21-24^{\circ} \mathrm{C}\right)$ for at least $10-15 \mathrm{~min}$ before testing. Only female I. scapularis were used in the tests. 


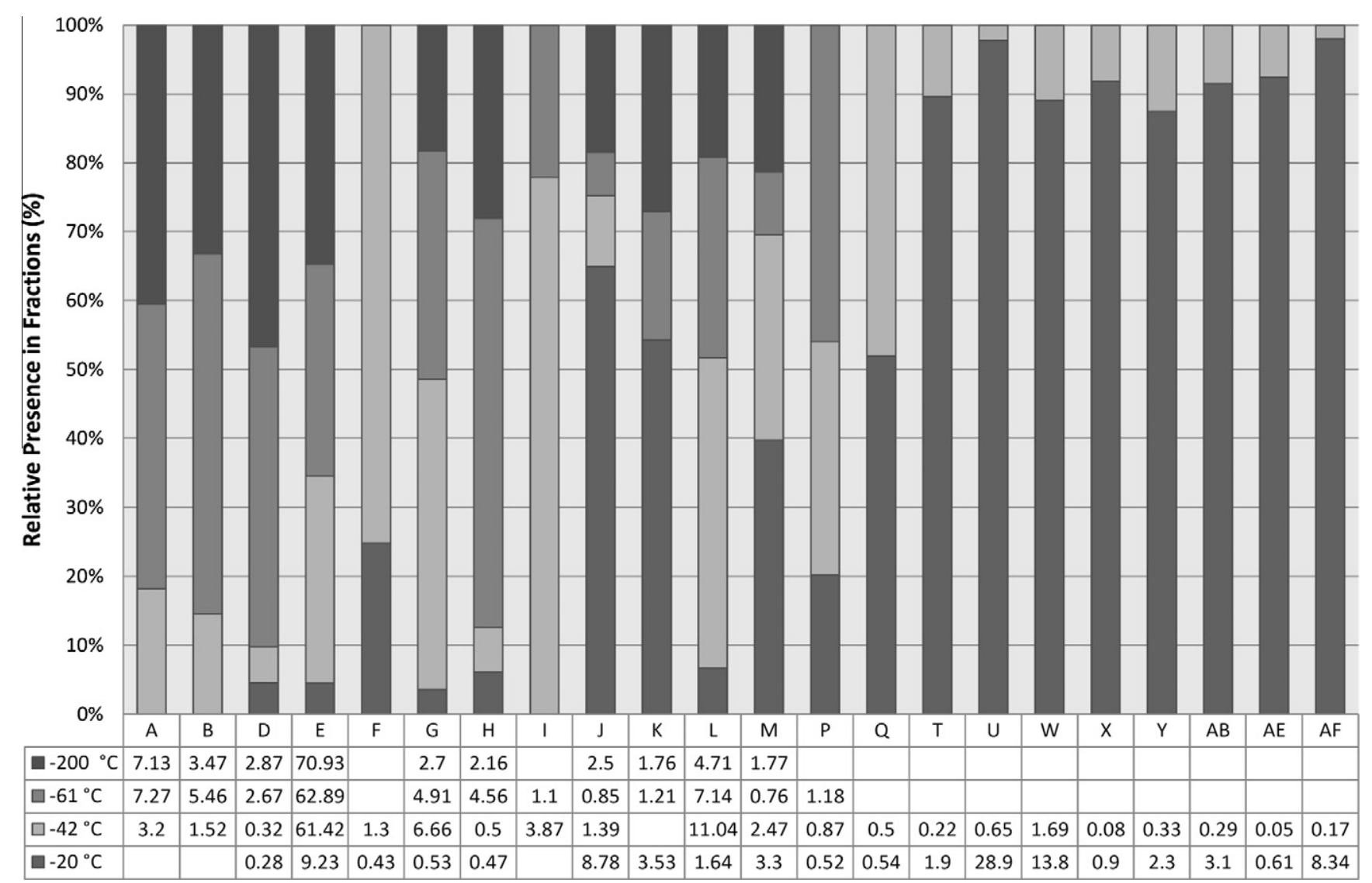

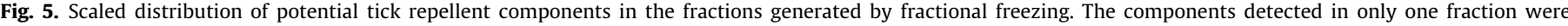
excluded for more relevant analysis. The entire list of components is shown in Table S3 in Supplementary data.

It was not necessary to screen the adult I. scapularis before testing as in the case with nymphs (Carroll et al., 2007; Schreck et al., 1995). However, the adult ticks were transferred from the rim of an open storage vial to the lower untreated portion of the filter paper by allowing an individual tick to crawl onto a slender wooden dowel ( $3 \mathrm{~cm}$ diam). The dowel was tilted at an angle of $>45^{\circ}$ from horizontal. As the tick approached the upper tip of the dowel, the tip of the dowel was held to the lower edge of the filter paper and the tick crawled onto the paper. Locations of the ticks were recorded at 1, 3, 5, 10, and 15 min after the 10 th tick was on the filter paper. Ticks were considered repelled if they remained on the lower untreated zone of the filter for $15 \mathrm{~min}$ or if they dropped off the strip without having crossed into the upper untreated zone. We scored repellency based on the locations of ticks at $15 \mathrm{~min}$. Ticks that climbed to the upper untreated zone were removed to prevent their return to the lower zones. Test solutions and acetone or EtOAc controls were tested in random order. A control was run each day that the extracts and DEET were tested. Ticks were tested in replicates of 10 ticks per combination of concentration of pondberry extracts or DEET. The extracts and DEET were tested against five replicates of $A$. americanum at $0.827,0.413,0.206,0.103$ and 0 (acetone control) $\mathrm{mg} / \mathrm{cm}^{2}$ filter paper. Four replicates of 10 adult $I$. scapularis each were tested against $0.413 \mathrm{mg}$ pondberry crude extract $/ \mathrm{cm}^{2}$ and two replicates of 10 ticks and one replicate of 11 ticks against the acetone control. Three replicates of $10 \mathrm{~A}$. americanum nymphs each were tested against 2000 and 0 (EtOAc) nmol sabinene and trans-sabinene hydrate $/ \mathrm{cm}^{2}$. Tests for repellency differences between components were conducted using the GLM (generalized linear models) function of the R software (R Development Core Team, 2009). This allowed us to model the counts as samples from binomial distributions, using the logit link function. We checked for over-dispersion by first estimating the models using the "family = quasibinomial" argument (this inflates the sampling error variance by the estimated over-dispersion, adjusting significance tests to be more conservative). If the over-dispersion parameter was near one (indicating no over-dispersion), the model was re-estimated using the "family = binomial" argument. For models with over-dispersion, $t$-statistics are output (for significance testing), for models without over-dispersion, $z$-statistics are output. The estimated dose to repel 50\% and 95\% percent of ticks and approximate 95\% fiducial (inverse regression) confidence limits was estimated using the dose.p function in the MASS package (Venables and Ripley, 2002).

\subsection{Fractional freezing}

Four different cold temperature baths $(-20,-42,-61$ and $-200^{\circ} \mathrm{C}$ ) were generated and high vacuum ( 700 mTorr) was applied to fractionate the collected crude essential oil (Fig. S5 in Supplementary data). The four temperatures were produced by $1: 1$ ethylene glycol: $\mathrm{H}_{2} \mathrm{O}$ controlled by a recirculating chiller $\left(-20^{\circ} \mathrm{C}\right)$, $\mathrm{CH}_{3} \mathrm{CN}\left(-42{ }^{\circ} \mathrm{C}\right)$ and $\mathrm{CH}_{3} \mathrm{Cl}_{3}\left(-61^{\circ} \mathrm{C}\right)$ cooled by adding dry ice, and liquid nitrogen $\left(-200{ }^{\circ} \mathrm{C}\right)$. The temperatures were maintained by adding coolants every $10 \mathrm{~min}$. Extraction of each collected oil fraction was completed as described in Section 4.3. GC-MS analysis of the fractions generated by the fractional freezing was carried out with an HP 6890 series GC, equipped with a split/splitless capillary injector, an HP 6890 Series injector autosampler, and a DB-5 ms column $(30 \mathrm{~m} \times 0.25 \mathrm{~mm} \times 0.25 \mu \mathrm{m}$, Agilent $)$. The GC was interfaced to an HP 5973 quadrupole mass selective detector through a transfer line set at $240{ }^{\circ} \mathrm{C}$. The injector temperature was $220^{\circ} \mathrm{C}$, and $1 \mu \mathrm{L}$ injections were performed in the split (1:10) mode. Column flow was set at a constant pressure of $10 \mathrm{psi}$, giving a nominal initial flow of $1.2 \mathrm{~mL} / \mathrm{min}$, using helium as carrier gas. The oven 
temperature was raised from 60 to $300^{\circ} \mathrm{C}$ at a rate of $3{ }^{\circ} \mathrm{C} / \mathrm{min}$ for a total run time of $80 \mathrm{~min}$. The filament was operated at $70 \mathrm{eV}$ with an emission current of $35 \mu \mathrm{A}$. The multiplier voltage was automatically set to $2094 \mathrm{~V}$. The ion source and quadrupole temperatures were $230{ }^{\circ} \mathrm{C}$ and $120^{\circ} \mathrm{C}$, respectively. The acquisition range was $\mathrm{m} / \mathrm{z} 35-800$ at 1.95 scans per second, starting $2.5 \mathrm{~min}$ after injection. Components of the four fractions were identified by the same way described at Section 4.4 and cross-checked with the more rigorous results from the GC and GC-MS analysis and NMR assignments of the crude pondberry oil for consistency (Table S3 in Supplementary data).

\section{Acknowledgments}

The authors thank Dr. Desmond Slade, Dr. Mei Wang and Dr. Nurhayat Tabanca for their technical assistance and Dr. Daneel Ferreira for manuscript prereview. We are grateful to Dr. Matt Kramer, USDA, ARS, Biometrical Consulting Service, Beltsville Agricultural Research Center, Beltsville, MD, for analyzing the tick data. We also thank James McCrary, Gabrielle Woodford, and Abdul Saboor Khan, USDA, ARS, IIBBL, Beltsville, MD, for conducting behavioral bioassays with ticks. This investigation was conducted in a facility constructed with support from research facilities improvement program C06 RR-14503-01 from the NIH National Center for Research Resources. Financial support was obtained from Kraft Food Global Inc.

\section{Appendix A. Supplementary data}

Supplementary data associated with this article can be found, in the online version, at http://dx.doi.org/10.1016/j.phytochem.2012. 05.001 .

\section{References}

Baratta, M.T., Dorman, H.J.D., Deans, S.G., Figueiredo, A.C., Barroso, J.G., Ruberto, G. 1998. Antimicrobial and antioxidant properties of some commercial essential oils. Flavour Frag. J. 13, 235-244.

Barnard, D.R., Bernier, U.R., Xue, R.-D., Debboun, M., 2007. Standard methods for testing mosquito repellents. In: Debboun, M., Frances, S., Strickman, D. (Eds.), Insect Repellents: Principles, Methods, And Uses. CRC, Boca Raton, FL, pp. 103110.

Barnard, D.R., Xue, R.-D., 2004. Laboratory evaluation of mosquito repellents against Aedes albopictus, Culex nigripalpus, and Ochlerotatus triseriatus (Diptera: Culicidae). J. Med. Entomol. 41, 726-730.

Bissinger, B.W., Roe, R.M., 2010. Tick repellents: past, present, and future. Pestic. Biochem. Physiol. 96, 63-79.

Briassoulis, G., Narlioglou, M., Hatzis, T., 2001. Toxic encephalopathy associate with use of DEET insect repellents: a case analysis of its toxicity in children. Hum. Exp. Toxicol. 20, 8-14.

Brown, A.W., 1983. Integrated mosquito control methodologies. Academic Press, New York.

Butchart, S.H.M., Walpole, M., Collen, B., van Strien, A., Scharlemann, J.P.W., Almond, R.E.A., Baillie, J.E.M., Bomhard, B., Brown, C., Bruno, J., Carpenter, K.E., Carr, G.M., Chanson, J., Chenery, A.M., Csirke, J., Davidson, N.C., Dentener, F., Foster, M. Galli, A., Galloway, J.N., Genovesi, P., Gregory, R.D., Hockings, M., Kapos, V., Lamarque, J.-F., Leverington, F., Loh, J., McGeoch, M.A., McRae, L., Minasyan, A. Morcillo, M.H., Oldfield, T.E.E., Pauly, D., Quader, S., Revenga, C., Sauer, J.R. Skolnik, B., Spear, D., Stanwell-Smith, D., Stuart, S.N., Symes, A., Tierney, M., Tyrrell, T.D., Vié, J.-C., Watson, R., 2010. Global biodiversity: indicators of recent declines. Science 328, 1164-1168.

Carroll, J.F., Klun, J.A., Debboun, M., 2005. Repellency of deet and SS220 applied to skin involves olfactory sensing by two species of ticks. Med. Vet. Entomol. 19, 101-106.

Carroll, J.F., Solberg, V.B., Klun, J.A., Kramer, M., Debboun, M., 2004. Comparative activity of deet and AI3-37220 repellents against the ticks Ixodes scapularis and Amblyomma americanum (Acari: Ixodidae) in laboratory bioassays. J. Med. Entomol. 41, 249.

Carroll, J.F., Cantrell, C.L., Klun, J.A., Kramer, M., 2007. Repellency of two terpenoid compounds isolated from Callicarpa americana (Lamiaceae) against Ixodes scapularis and Amblyomma americanum ticks. Exp. Appl. Acarol. 41, 215-224.

CDC, 2007. Reported Lyme disease cases by state, 1993-2006. (http://www.cdc. gov/ncidod/dvbid/lyme).
Center for Plant Conservation, 2011. www.centerforplantconservation.org/ Collection/CPC ViewProfile.asp?CPCNum=630 accessed 5.17.2011.

Clem, Havemann D., Raebel, M., 1993. Insect repellent (N,N-diethyl-m-toluamide) cardiovascular toxicity in an adult. Ann. Pharmacother. 27, 289-293.

de Mendonça, F.A.C., da Silva, K.F.S., dos Santos, K.K., Ribeiro Júnior, K.A.L., Sant'Ana, A.E.G., 2005. Activities of some Brazilian plants against larvae of the mosquito Aedes aegypti. Fitoterapia 76, 629-636.

DeBiasi, R.L., Tyler, K.L., 2006. West Nile virus meningoencephalitis. Nat. Clin. Pract. Neuro. 2, 264-275.

ESO 2000, 1999. The complete database of essential oils. Boelens Aroma Chemical Information Service, The Netherlands.

Evans, S.R., Korch, G.W., Lawson, M.A., 1990. Comparative field evaluation of permethrin and DEET-treated military uniforms for personal protection against ticks (Acari). J. Med. Entomol. 27, 829-834.

Ginsberg, H.S., Ewing, C.P., Connell, A.F., Bosler, E.M., Daley, J.G., Sayre, M.W., 1991. Increased population densities of Amblyomma americanum (Acari: Ixodidae) on Long Island, New York. J. Parasitol. 77, 493-495

Goddard, J., Varela-Stokes, A.S., 2009. Role of the lone star tick, Amblyomma americanum (L.), in human and animal diseases. Vet. Parasitol. 160, 1-12.

Guerrini, A., Sacchetti, G., Muzzoli, M., Moreno Rueda, G., Medici, A., Besco, E., Bruni, R., 2006. Composition of the volatile fraction of Ocotea bofo Kunth (Lauraceae) calyces by GC-MS and NMR Fingerprinting and its antimicrobial and antioxidant activity. J. Agric. Food Chem. 54, 7778-7788.

Hawkins, T.S., Schiff, N.M., Gardiner, E.S., Leininger, T., Devall, M.S., Wilson, D., Hamel, P., Mccown, D.D., Connor, K., 2007. Micropropagation of the endangered shrub pondberry (Lindera melissifolia [Walt.] blume). Hortscience 42, 407-409.

Jaenson, T.G.T., Garboui, S., Pålsson, K., 2006. Repellency of oils of lemon eucalyptus, geranium, and lavender and the mosquito repellent MyggA natural to Ixodes ricinus (Acari: Ixodidae) in the laboratory and field. J. Med. Entomol. 43, 731736.

Jensen, N. J., 2007. http://www.cnpsci.org/PlantInfo/RarePlants/VMM_FinalReport_ 042607minus_sensitive_info.pdf.

Joshi, S.C., Verma, A.R., Mathela, C.S., 2010. Antioxidant and antibacterial activities of the leaf essential oils of Himalayan Lauraceae species. Food Chem. Toxicol. $48,37-40$

Joulain, D., Koenig, W.A., 1998. The Atlas of spectra data of sesquiterpene hydrocarbons. EB-Verlag, Hamburg, Germany.

Katritzky, A.R., Wang, Z., Slavov, S., Dobchev, D.A., Hall, C.D., Tsikolia, M., Bernier, U.R., Elejalde, N.M., Clark, G.G., Linthicum, K.J., 2010. Novel carboxamides as potential mosquito repellents. J. Med. Entomol. 47, 924-938.

Kline, D.L., Bernier, U.R., Posey, K.H., Barnard, D.R., 2003. Olfactometric evaluation of spatial repellents for Aedes aegypti. J. Med. Entomol. 40, 463-467.

Koenig, W.A., Joulain, D., Hochmuth, D.H., 2004. Terpenoids and related constituents of essential oils. University of Hamburg, Institute of Organic Chemistry, Hamburg, Germany.

Kotiaho, J.S., 2005. Predicting the risk of extinction from shared ecological characteristics. Proc. Natl. Acad. Sci. U S A 102, 1963-1967.

Kubeczka, K.H., Formácek, V., 2002. Essential oils analysis by capillary gas chromatography and carbon-13 NMR Spectroscopy, second ed. Wiley, New York.

Lee, J.C., Yang, X., Schwartz, M., Strobel, G., Clardy, J., 1995. The relationship between an endangered North American tree and an endophytic fungus. Chem. Biol. 2, 721-727.

Lockhart, B.R., Gardiner, E.S., Leininger, T.D., Connor, K.F., Hamel, P.B., Schiff, N.M. Wilson, A.D., Devall, M.S., 2006. Flooding facility helps scientists examine the ecophysiology of floodplain species used in bottomland hardwood restorations. Ecol. Restorat. 24, 151-157.

Matthews, J.S., Coggeshall, N.D., 1959. Concentration of impurities from organic compounds by progressive freezing. Anal. Chem. 31, 1124-1125.

McLafferty, F.W., Stauffer, D.B., 1989. The Wiley/NBS registry of mass spectral data. J. Wiley and Sons, New York.

Moriarity, D.M., Bansal, A., Cole, R.A., Takaku, S., Haber, W.A., Setzer, W.N., 2007. Selective cytotoxic activities of leaf essential oils from Monteverde, Costa Rica. Nat. Prod. Commun. 2, 1263-1268.

Müller, G.C., Junnila, A., Kravchenko, V.D., Revay, E.E., Butler, J., Schlein, Y., 2008. Indoor protection against mosquito and sand fly bites: A comparison between citronella, linalool, and geraniol candles. J. Am. Mosq. Control Assoc. 24, 150153.

Parola, P., Raoult, D., 2001. Ticks and tickborne bacterial diseases in humans: an emerging infectious threat. Clin. Infect. Dis. 32, 897-928.

Peterson, C., Coats, J., 2001. Insect repellents - past, present and future. Pestic. Outlook 12, 154-158.

Pitman, N.C.A., Jørgensen, P.M., 2002. Estimating the size of the world's threatened flora. Science 298, 989.

Posey, K.H., Schreck, C.E., 1981. An airfow apparatus for selecting female mosquitoes for use in repellent and attraction studies. Mosq. News 41, 566568 .

R Development Core Team, 2009. R: A language and environment for statistical computing. R Foundation for Statistical Computing, Vienna, Austria.

Radford, A.E., Ahles, H.E., Bell, C.R., 1968. Manual of the vascular flora of the Carolinas. University of North Carolina Press, Chapel Hill.

Rozendaal, J.A., 1997. Mosquitoes and other biting Diptera. World Health Organization, Geneva, Switzerland.

Samarasekera, R., 2005. Mosquitocidal activity of leaf and bark essential oils of Ceylon Cinnamomum zeylanlcum. J. Essent. Oil Res. 17, 301. 
Schmidt, E., Jirovetz, L., Buchbauer, G., Eller, G.A., Stoilova, I., Krastanov, A., Stoyanova, A., Geissler, M., 2006. Composition and antioxidant activities of the essential oil of cinnamon (Cinnamomum zeylanicum Blume) leaves from Sri Lanka. J. Essent. Oil Bear. Pl. 9, 170-182.

Schreck, C.E., Fish, D., McGovern, T.P., 1995. Activity of repellents applied to skin for protection against Amblyomma americanum and Ixodes scapularis ticks. J. Am. Mosq. Control Assoc. 11, 136-140.

Semwal, A.D., Sharma, G.K., Arya, S.S., 1999. Pro- or antioxygenic activity of tejpat (Cinnamomum tamala) and red chilli (Capsicum annum) in sunflower oil. J. Sci. Food Agric. 79, 1733-1736.

Sköld, R., Suurkuusk, J., Wadsö, I., 1976. Thermochemistry of solutions of biochemical model compounds 7. Aqueous solutions of some amides, tbutanol and pentanol. J. Chem. Thermodyn. 8, 1075-1080.

Sonenshine, D.E., 1993. Biology of ticks. Oxford University Press, New York.

Spielman, A., Wilson, M.L., Levine, J.F., Piesman, J., 1985. Ecology of Ixodes damminiborne human babesiosis and Lyme disease. Annu. Rev. Entomol. 30, 439-460.

U. S. Fish and Wildlife Service, 1986. Endangered and threatened wildlife and plants: Determination of endangered status for Lindera melissifolia. Fed. Regist. 51, 27495-27499.
U. S. Fish and Wildlife Service, 1993. Recovery plan for pondberry (Lindera melissifolia). U.S. Fish and Wildlife Service, Atlanta, GA.

USDA, 2011. <http://plants.usda.gov/threat.html> accessed 4.10.2011.

Venables, W.N., Ripley, B.D., 2002. Modern Applied Statistics with S, fourth ed. Springer, New York.

Weldon, P., Carroll, J., Kramer, M., Bedoukian, R., Coleman, R., Bernier, U., 2011. Anointing chemicals and hematophagous arthropods: Responses by ticks and mosquitoes to citrus (Rutaceae) peel exudates and monoterpene components. J. Chem. Ecol. 37, 348-359.

Yang, Y.C., Lee, E.H., Lee, H.S., Lee, D.K., Ahn, Y.J., 2004. Repellency of aromatic medicinal plant extracts and a steam distillate to Aedes aegypti. J. Am. Mosq. Control Assoc. 20, 146-149.

Yap, H.H., Jahangir, K., Zairi, J., 2000. Field efficacy of four insect repellent products against vector mosquitoes in a tropical environment. J. Am. Mosq. Control Assoc. 16, 241-244. 